Oliveira, G.H., Servidoni, L.E., Spalevic, V., Gaspar Junior, L.A., Mincato, R.L. (2021): Geological heritage management and preservation instruments: Case study of the municipality of Conceição da Aparecida, Minas Gerais - Brazil. Agriculture and Forestry, 67 (3): 71-82

DOI: 10.17707/AgricultForest.67.3.06

\begin{abstract}
Gabriel Henrique de OLIVEIRA ${ }^{1}$, Lucas Emanuel SERVIDONI, Velibor SPALEVIC ${ }^{2,3}$, Lineo Aparecido GASPAR JUNIOR ${ }^{1}$, Ronaldo Luiz MINCATO ${ }^{I}$
\end{abstract}

\title{
GEOLOGICAL HERITAGE MANAGEMENT AND PRESERVATION INSTRUMENTS: CASE STUDY OF THE MUNICIPALITY OF CONCEIÇÃO DA APARECIDA, MINAS GERAIS - BRAZIL
}

\section{SUMMARY}

Brazil is a country that has a vast territory and contains many natural landscapes features and immense variety of rocks, shapes and structures of great aesthetic and scientific value. Geosites are areas that have numerous geological potentials, where these characteristics are notable from a scientific, didactic or touristic point of view. In this sense, this work carried out a cataloguing of geosites in the municipality of Conceição da Aparecida, in the south of Minas Gerais state aiming at the geoconservation of the geological heritage, the balanced use of natural resources and the identification of geosites. The lands of the study area belong to several units of the crystalline basement entitled Campos Gerais Formation, Carrancas Group, Petunia Complex, Varginha-Guaxupé Complex and Andrelândia Complex composed essentially by gneissic rocks. The development of this work consisted in the construction of a qualitative base on the studied area from the analysis of topographic maps, the use of GIS and later field activity, laboratory analysis and the elaboration of the results. In this way, the relationship between man and nature can be evidenced from the proposals for geoconservation and the identification of these areas for future generations. Thus, the integrity of nature and the best quality of life for man will be maintained. he scientific and local community will be informed about the issues of geographic space, enabling investments and better management practices in the area.

Keywords: Geosites; Geodiversity; Geoconservation; Minas Gerais; Brazil

\section{INTRODUCTION}

Geodiversity consists of the variety of geological environments, phenomena and active processes that give rise to landscapes, rocks, minerals,

\footnotetext{
${ }^{1}$ Gabriel Henrique de Oliveira, Lucas Emanuel Servidoni, Lineo Aparecido Gaspar Junior, Ronaldo Luiz Mincato (corresponding author: ronaldo.mincato@unifal-mg.edu.br), Federal University of Alfenas, UNIFAL-MG, Alfenas, Minas Gerais, BRAZIL;

${ }^{2}$ Velibor Spalevic, University of Montenegro, Biotechnical Faculty Podgorica, MONTENEGRO;

${ }^{3}$ Velibor Spalevic, University of Montenegro, Geography, Faculty Philosophy, MONTENEGRO. Notes: The authors declare that they have no conflicts of interest. Authorship Form signed online. Recieved:01/07/2021 
fossils, soils, and other surface deposits that support the development of life. Based on this definition, it is possible to observe the relevance of studies on geodiversity, not only due to past changes, but also due to potential future impacts, adverse or favourable. Thus, the study and maintenance of geodiversity becomes increasingly important for the various areas of Geosciences (Brilha and Pereira, 2014; Brilha, 2016).

Geosites represent places of geological interest that have uniqueness due to their scientific, educational, cultural, and touristic value. Due to their strategic value, geosites must be identified, studied, and preserved for intrinsic scientific reasons or to serve humans with attributes of scenic beauty or supply natural resources such as water and mineral commodities (De Wever et al., 2015).

Geomorphological mapping has tremendously evolved over the past decades (Frankl et al., 2016) based approaches and the interpretation of stereoscopic aerial photographs. The mapping and study of geosites are recent in tropical regions and in southern Minas Gerais there are no considerable studies on this subject. Therefore, the absence of strategic information on geodiversity can lead to serious problems related to the socio-environmental impact of the absence of public conservation policies (Garcia et al., 2018). Among them, we can mention the inappropriate use of natural resources, pollution and, in some cases, fatal accidents due to ignorance or lack of information and safety systems (Reverte and Garcia, 2016; Reverte et al., 2019).

The set of geosites inventoried in the Taubate Hydrographic Basin carried out by Reverte et al. (2019) identified 18 geosites. Therefore, they adopted geological categories to guide the identification of geosites during the inventory. The set of geosites contemplated have rock outcrops with high scientific and educational value and potential areas for the establishment of natural heritage. Then, Reverte et al. (2019) collaborated with strategic information for the stimulation of public policies for the conservation of geopatrimony.

The study of geodiversity is of interest for the development of an environmentally sustainable society, helps the emergence of environmental policies, the implementation and management of conversation units that address the uniqueness of geoheritages and contribute to the conservation of natural resources and encourage environmental education in its places (Brilha, 2016; Pitombeira, 2018; Reverte et al., 2019).

Given the above, this work identified and classified the geosites of the Conceição da Aparecida municipality, in the Minas Gerais state, based on the proposal by Brilha (2016). The work also adapted the geosite identification and quantification method to tropical conditions and proposed measures to control and promote the environmental and socioeconomic sustainability of the area.

\section{MATERIAL AND METHODS}

The study area (Figure 1) covers the rural area of the Conceição da Aparecida municipality, south of the of Minas Gerais state - Brazil. The 
municipality is located between the geographic coordinates $21^{\circ} 00^{\prime} 00^{\prime \prime}$ and $21^{\circ} 15^{\prime} 00^{\prime \prime} \mathrm{S}$ and $46^{\circ} 25^{\prime} 00^{\prime \prime}$ and $46^{\circ} 00^{\prime} 00^{\prime \prime} \mathrm{W}$.

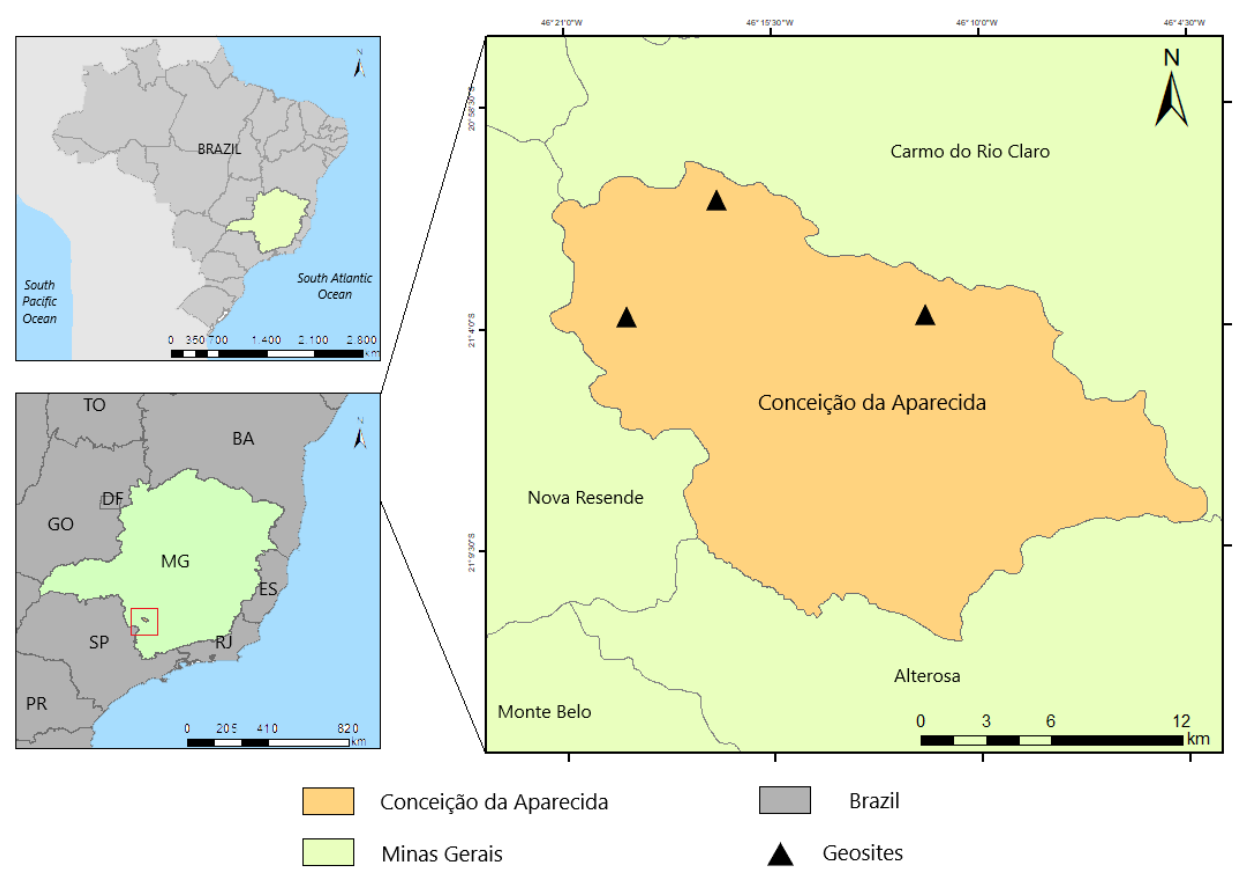

Figure 1. Location map of the of Conceição da Aparecida municipality, southern of Minas Gerais state - Brazil.

Located in the mesoregion of Alfenas in southern Minas Gerais, the municipality was founded on January 1, 1944 and has a population of 10,351 inhabitants according to the Brazilian Institute of Geography and Statistics IBGE (IBGE, 2021). The main economic activity of the wider region and in the specific municipality is the traditional planting of coffee (Bolleli et al., 2020; Tavares et al., 2019). Tourist activities are concentrated during the festive periods of the city and in the hot season with ecotourism in the hydrographic region of Furnas Hydroelectric Power Plant Reservoir.

The geology of the study area consists of metamorphic rocks, which are mainly gneisses containing intercalations of shales in addition to metagabbros (Turbay and Valeriano, 2012). The main geological formations in the area are illustrated in figure 2, namely: the Campos Gerais Complex, Fortaleza de Minas Group, undivided Fortaleza de Minas and Andrelândia (Gaspar Junior et al., 2010; SISEMA, 2019).

The digital map of soil classes were produced based on the Minas Gerais State Soil Map, scale 1:650,000 (Santana et al., 2021; UFV et al., 2010). The predominance of soils in the studied region is of red and yellowish Latosols and red yellow Argisols, with well-defined horizons and medium portion of humus 
cover (UFV et al., 2010). These have a generally sandy/clay texture, with a granular structure, with high porosity and well drained (Gaspar Junior et al., 2010). Geomorphology comprises both quantitative and qualitative explanations of landscapes and landforms, as well as processes investigations and process interactions creating these forms in temporal and spatial scales (Curovic et al., 2019; Hazbavi, 2018; Renschler and Harbor, 2002).

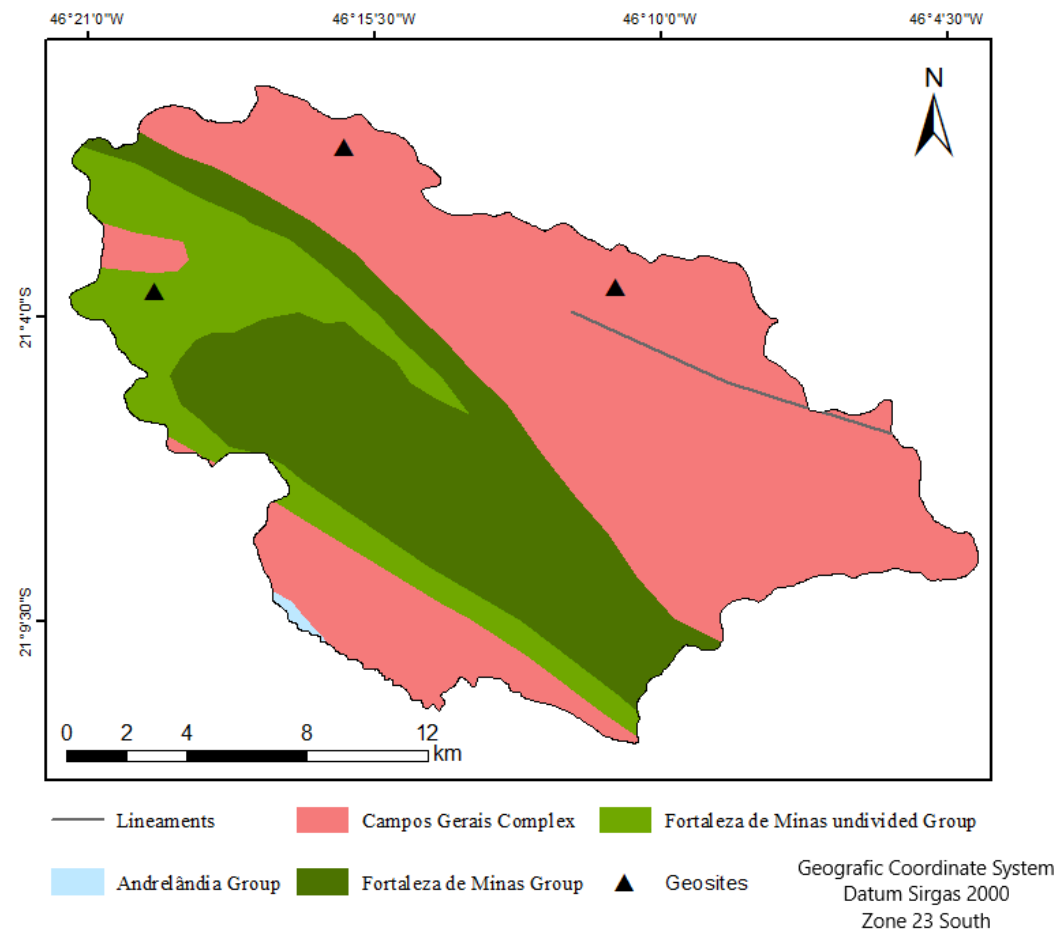

Figure 2. Geology Map of the of Conceição da Aparecida municipality, Minas Gerais state - Brazil. Data source: SISEMA (2019).

The local geomorphology consists of the Rio Grande Plateau and has altitudes below 1,000 meters, such as the Serras do Veado and Ibituruna, inserted in the context of seas of hills in the south of Minas Gerais (Silva, 2012).

The predominant morph climatic domain is the Atlantic Forest, with seasonal semi deciduous forest and the Cerrado (Savanna) associated with high altitudes. However, native vegetation has mostly been replaced by pastures and coffee cultivation (Scolforo et al., 2008). The climate according to Köppen classification is humid subtropical (Cwa), with well-defined seasons, with a hot and humid between October and March and a hot and cold between April and September (Sparovek et al., 2007; Aquino et al., 2012).

At first, a bibliographical review on Geoconservation and Geosites was carried out, focusing on the relevance of the subject for science and society. Thus, 
information regarding the physical aspects of the study area was collected and interpreted based on the satellite images, topographic maps and information available in the literature (Brilha and Pereira, 2014; Brilha, 2016; Reverte et al., 2019). GIS and Remote Sensing tools are obvious complements to geoheritage research and conservation, due to their applicability across all facets of the research and conservation lifecycle (Sestras et al., 2019; Williams, 2019).

Subsequently, fieldwork was carried out to collect data, which were analysed and synthesized using ArcGIS 10.5 geographic information systems.

Then, potential geosites were selected for educational, economic and tourist use. For this purpose, the field form adapted from Brilha (2016, Table 1).

Table 1: Geosite Classification Table

\begin{tabular}{ll}
\hline Location/Date: & Sample: \\
Coordinate: & Altitude: \\
Accessibility: & Conservation state: \\
Impacts: & Potential of use: \\
Interest: & Vulnerability: \\
Protection measures: & Physical aspects:
\end{tabular}

Source: Adapted from Brilha (2016).

Subsequently, the process of quantification of geosites was carried out following the proposal adapted of Brilha (2016). The quantification assigned grades to the geosites depending on their state of preservation. The criteria adopted for the quantification of geosites were: $\mathrm{A}$ - their intrinsic value; $\mathrm{B}$ - its potential for use and C - The need for protection (Table 2).

Table 2: Parameter for quantitative assessment

\begin{tabular}{llll}
\hline & \multicolumn{3}{c}{ Parameter for Quantitative Assessment } \\
\hline & Intrinsic (a) & Land use (b) & Protection (c) \\
\hline Parameter 1 & A.1 Abundance & B.1 Potential use & C.1 Potential dangers \\
Parameter 2 & A.2 Extension & B.2 Condition & C.2 Current situation \\
Parameter 3 & A.3 Geological pr. & B.3 Accessibility & C.3 Mineral Potential \\
Parameter 4 & A.4 Diversity & B.4 Proximity to villages & C.4 Fragility \\
Parameter 5 & A.5 Conservation & ------ & ------ \\
\hline
\end{tabular}

Source: Adapted from Brilha (2016).

These grades range from one to five, with lower grades being areas with less relevance and high grades being more notable areas. Finally, the possibility of comparison and identification of the potential use of each element studied (Carcavilla et al., 2009).

The vulnerability of geosites was classified as low, medium and high according to the criteria classified in the field by Table 1 and 2. Being: low when the sum of the criteria adopted is less than 15, medium when the values are from 15 to 19 and high when greater than 19. Then, possible land use and occupation actions for the identified geosites were presented and discussed, taking into account their vulnerability according to the method adapted from Brilha (2016). 


\section{RESULTS AND DISCUSSION}

The analysis performed allowed to identify three main geosites with water, landscape and mineral interest, they are: Pedra Molhada Waterfall, Failure Waterfall and a Manganese Deposit. The summary of the quantification of the criteria adopted to classify the vulnerability of geosites is presented in Table 3.

Table 3: Summary of the analysis and classification of geosites.

\begin{tabular}{|c|c|c|c|c|c|c|c|c|c|c|c|c|c|c|}
\hline \multirow[b]{3}{*}{ GEOSITE } & \multicolumn{14}{|c|}{ PARAMETER } \\
\hline & \multicolumn{6}{|c|}{ INTRISEC } & \multicolumn{4}{|c|}{ LAND USE } & \multicolumn{4}{|c|}{ PROTECTION } \\
\hline & A1 & A2 & $\mathbf{A 3}$ & $\bar{A}$ & 4 & A5 & B1 & $\mathbf{B 2}$ & B3 & B4 & C1 & $\mathrm{C} 2$ & C3 & C4 \\
\hline $\begin{array}{l}\text { PEDRA MOLHADA } \\
\text { WATERFALL }\end{array}$ & 5 & & & 5 & 5 & 3 & 5 & & 4 & 5 & 5 & & 5 & 5 \\
\hline TOTAL & \multicolumn{6}{|c|}{21} & \multicolumn{4}{|c|}{19} & \multicolumn{4}{|c|}{20} \\
\hline CLASSIFICATION & \multicolumn{6}{|c|}{ HIGH } & \multicolumn{4}{|c|}{ MEDIUM } & \multicolumn{4}{|c|}{ HIGH } \\
\hline $\begin{array}{c}\text { FAILURE } \\
\text { WATERFALL }\end{array}$ & 5 & & & 5 & 4 & 3 & 5 & & 5 & 5 & 5 & & 5 & 5 \\
\hline TOTAL & \multicolumn{6}{|c|}{19} & \multicolumn{4}{|c|}{20} & \multicolumn{4}{|c|}{20} \\
\hline CLASSIFICATION & \multicolumn{6}{|c|}{ MEDIUM } & \multicolumn{4}{|c|}{ HIGH } & \multicolumn{4}{|c|}{ HIGH } \\
\hline $\begin{array}{l}\text { MANGANESE } \\
\text { DEPOSIT }\end{array}$ & 5 & & & 5 & 4 & 5 & 5 & & 5 & 5 & 5 & & 5 & 5 \\
\hline TOTAL & & & & 22 & & & & & 20 & & & & 20 & \\
\hline CLASSIFICATION & & & & $\mathrm{HIGH}$ & & & & & HIGH & & & & HIGH & \\
\hline
\end{tabular}

Legend: A1: Abundance; A2: Extension; A3: Geological processes; A4: Diversity; A5: Conservation; B1: Potential use; B2: Condition; B3: Accessibility; B4: Proximity to Villages; C1: Potential Dangers; C2: Current Situtation; C3: Mineral Potential C4: Fragility. Source: Adapted from Brilha (2015).

The Pedra Molhada Waterfall geosite (Figure 4 - item 1) is located between the municipalities of Conceição da Aparecida and Carmo do Rio Claro, approximately $20 \mathrm{~km}$ from the two urban areas, at coordinates $46^{\circ} 14^{\prime} 58^{\prime \prime} \mathrm{W}$ and $21^{\circ} 00^{\prime} 22^{\prime \prime} \mathrm{S}$. Access to these geosites was classified as difficult due to the precarious situation of rural roads and their distance from the urban centre.
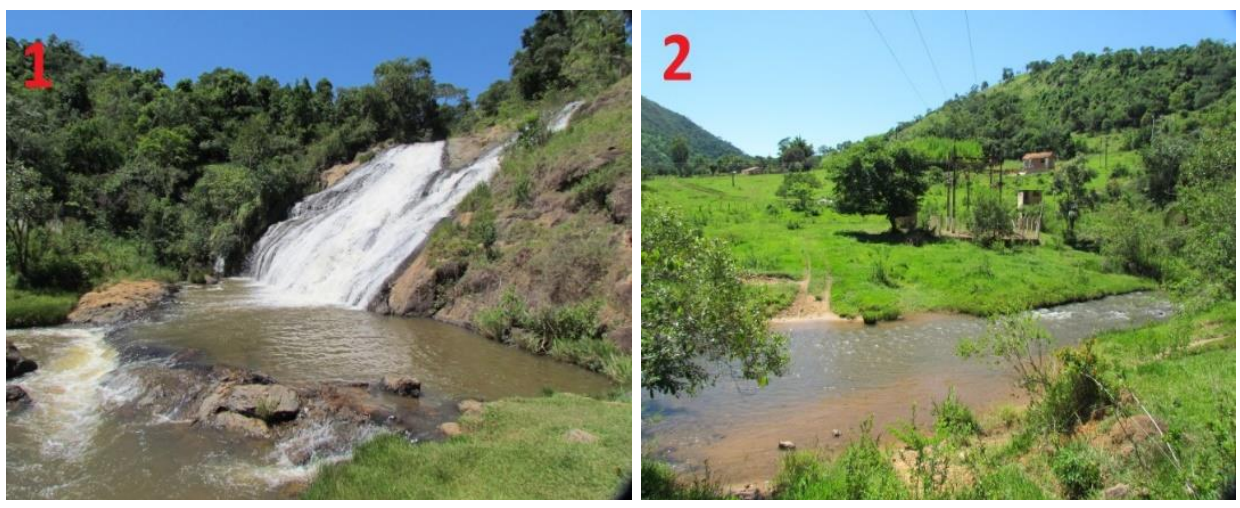

Figure 4a - Photographs 1: Pedra Molhada Waterfall; 2: Abandoned buildings from the old hydroelectric plant. 


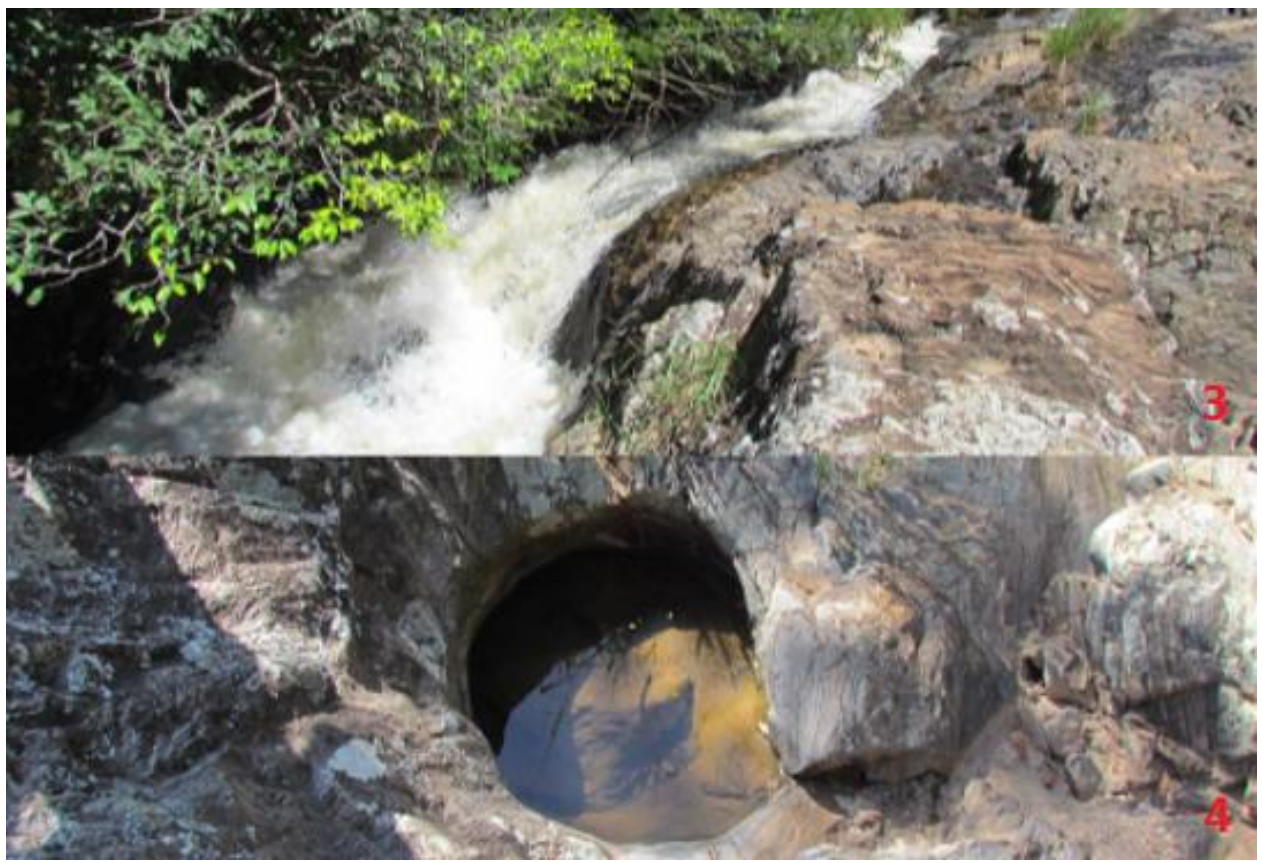

Figure $4 \mathrm{~b}-$ Photograph 3: Water flow at the top of the waterfall and

Photograph 4: The pots formed by the abrasion of the rock.

Conceição da Aparecida municipality, Minas Gerais state - Brazil.

The area is in a good state of conservation; however, disordered tourism contributes to increasing the area's vulnerability. We suggest that the owner of the land where the geosite is located and public authorities promote conservation actions and environmental education. Thus, it is recommended to install environmental awareness boards, distribute educational pamphlets and install dumpsters on site. As demonstrated by Choque (2021) and Ruíz et al. (2021) environmental education allows strengthening the human relationship with the environment. This encourages specific actions for environmental conservation, such as reducing consumerism, recycling, and the proper use of natural resources. As a result, they directly impact the quality of ecosystems as they reduce exposure to imminent risks.

Due to the intense hydrological dynamics in the area, the gneissic rocks are highly altered, as shown in Figure 2 - items 3 and 4 . At this point an old hydroelectric power plant is disabled. This improvement can be used as an operational basis for the development of activities related to scientific research, education and socio-educational practices combined with local tourism. This type of reconciliation of educational practices combined with leisure can generate satisfactory results in reducing environmental impacts due to the misuse of public space (Ruíz et al., 2021). 
Among the viable socio-educational practices, we can suggest the implementation of a natural history museum and a living space. In this way, it is possible to reconcile the conservation of the area with educational practices aimed at raising awareness about the use and conservation of natural resources and the sustainable economic development of local communities.

The second Fault Waterfall geosite is illustrated in Figure 5 and is located $15 \mathrm{~km}$ from Conceição da Aparecida at the coordinate 46 $10^{\prime \prime} 54^{\prime} \mathrm{W}$ and $21^{\circ} 3^{\prime \prime}$ $33^{\prime} \mathrm{S}$. The site is highlighted due to a change in relief caused by a geological fault (Figure 5). Therefore, it is a point of interest for scientific development purposes due to its geological condition considered didactic for the teaching of geosciences.
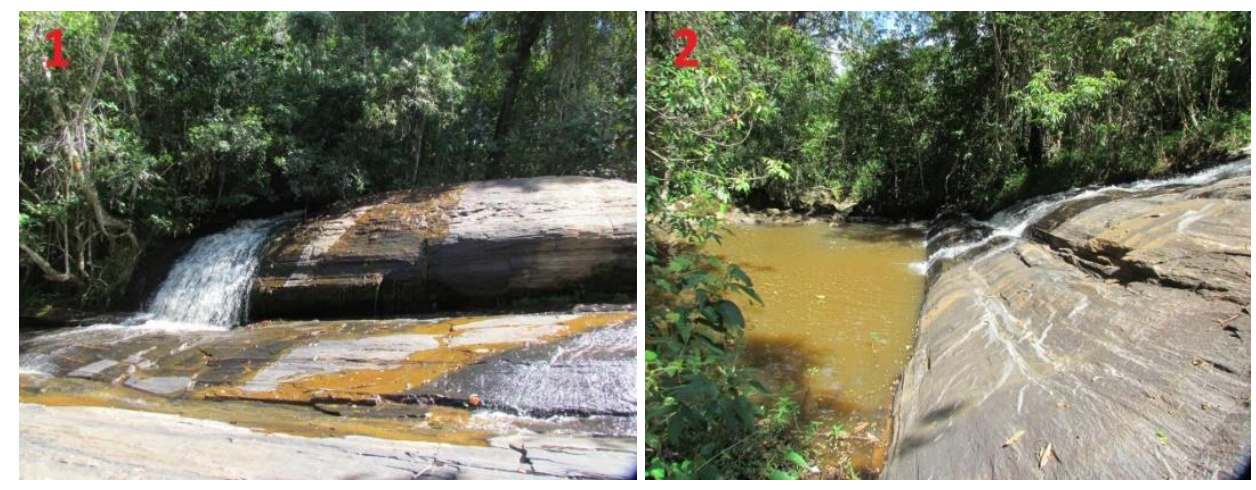

Figure 5. Fault Waterfall. Photograph 1: Waterfall and 2: Fault plane with stretched feldspar crystals, which suggest a geological fault site. Conceição da Aparecida municipality, Minas Gerais state - Brazil.

The area was classified as high vulnerability due to the presence of the geological fault. It is worth noting that it is inactive. In this location, constructions of any origin should be avoided, as instability in the area can vary. Therefore, access to this point must be controlled. Misuse of this site can compromise the quality of surface and groundwater. Thus, the potential for using this geosite is scientific and didactic due to the complexity of the elements that make up the landscape. If it is decided to use it for tourist purposes, it is necessary to establish measures to protect users, such as trained personnel, security measures and adequate cleaning.

The next geosite was called Manganese Deposit (Figure 6) and is $21 \mathrm{~km}$ from the urban perimeter of Conceição da Aparecida at $46^{\circ} 19^{\prime \prime} 45^{\prime} \mathrm{W}$ and $21^{\circ} 3^{\prime \prime}$ 33" S. Access is difficult through dirt roads precarious. The use of the local soil is for coffee cultivation, being remarkable the absence of native forest in the place. The exposure of soil and rock to climatic action favours soil losses due to water erosion as pointed out in the literature (Renard et al., 1997; Prochnow et al., 2016). 


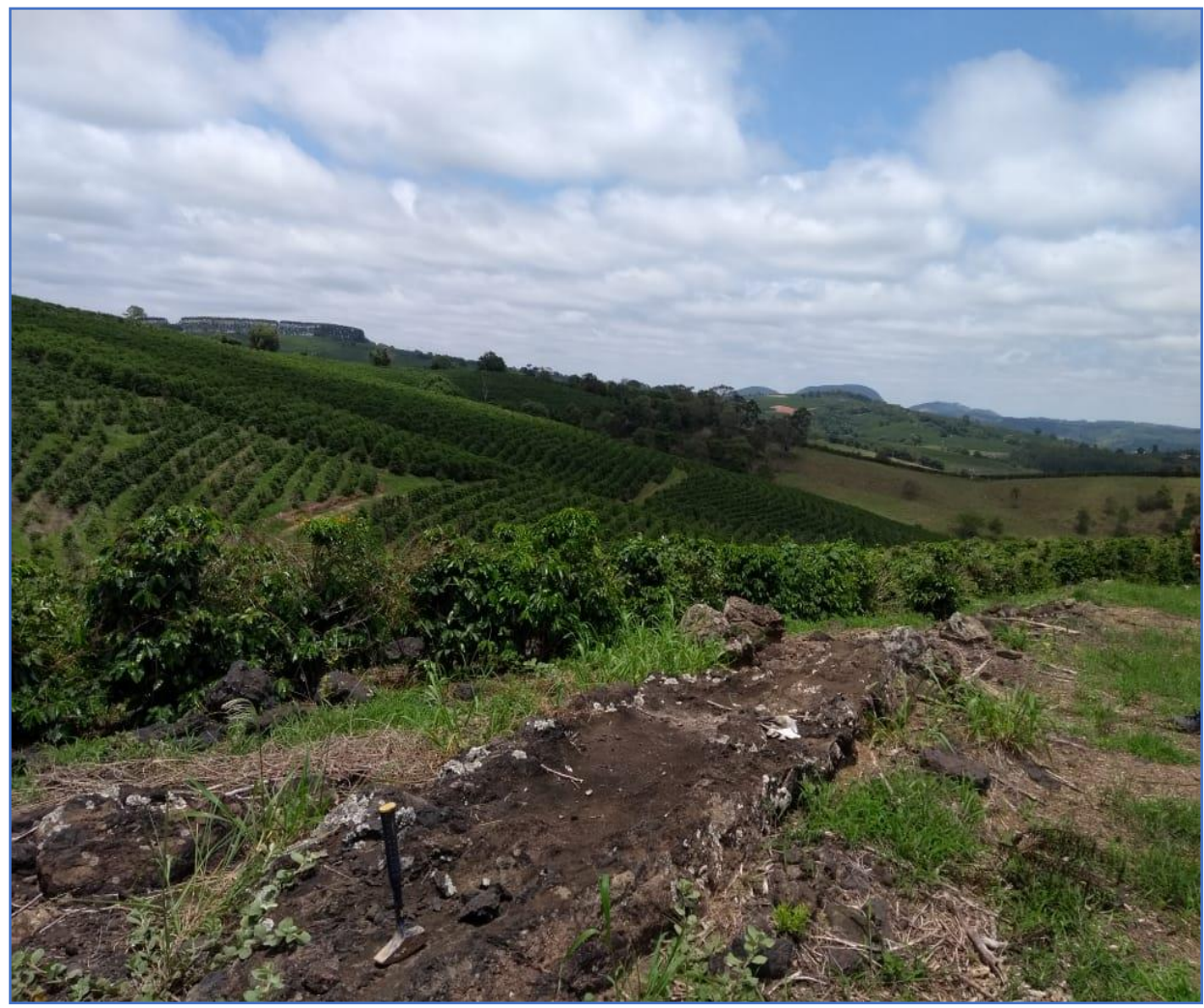

Figure 6. Manganese deposit exposed in a coffee cultivation. Conceição da Aparecida municipality, Minas Gerais state - Brazil.

The main rocks in the area have the presence of manganese ore. Manganese is an important element in the steel industry, as a deoxidizing agent; due to this factor its presence generates economic interest (Afonso, 2019). This manganese deposit from Conceição da Aparecida extends for approximately 5 $\mathrm{km}$, containing minerals such as quartz, manganite, pyrolusite, psilomelane and cryptomelane.

At the Manganese Deposit geosite, since it is a mineral extraction point, proposals and projects for land use and occupation should be more restricted. The area is exposed and therefore vulnerable to environmental impacts such as soil loss due to water erosion. Thus, the move away from coffee cultivation and the recovery of native forest are essential to promote the sustainability of the use of the geosite.

Brazil has enormous geotouristic potential and favourable conditions to fully develop this activity, in order to enjoy the social benefits it can offer. One of the main benefits is to allow tourists to know the geological heritage that makes up the geotouristic scenario, leading the community to value it and, consequently, promote its geoconservation in a sustainable way (Henriques et al., 2011). 


\section{CONCLUSIONS}

The adaptation of the method of Brilha allowed us to objectively point out the elements that made it possible to classify the vulnerability of a geosite to environmental impacts in conditions of a tropical region.

The geosites covered in this work were classified as medium and high vulnerability. This classification was due to its intrinsic factors such as land use and occupation, presence of pollution and its conservation status.

The results allowed pointing out actions that aim to maintain the environmental balance in the use of geosites. Among the possible actions to maintain the sustainability of the geosites were: reforestation, establishment of projects aimed at reconciling environmental conservation and socioeconomic development.

\section{ACKNOWLEDGEMENTS}

To the Coordenação de Aperfeiçoamento de Pessoal de Nível Superior (CAPES), for the financing of the study - Financial Code 001. The authors are grateful to the anonymous reviewers and the Editorial team for their insightful comments and suggestions.

\section{REFERENCES}

Afonso, J.C. (2019): Manganês no Brasil: descoberta, extração, consumo e comercialização numa perspectiva histórica. Química Nova, 42(10): 1172-1183.

Aquino, R.F., Silva, M.L.N., De Freitas, D.A.F., Curi, N., Mello, C.R., Avanzi, J.C. (2012): Spatial variability of the rainfall erosivity in southern region of Minas Gerais State, Brazil. Ciência e Agrotecnologia, 36(1): 533 -542.

Bolleli, T.M., Lense, G.H.E., Santana, D.B., Moreira, R.S., Sestras, P., Spalevic, V. \& Mincato, R.L. (2020): Estimates of soil losses in watershed under tropical of altitude climate in Brazil. Agriculture and Forestry, 66(1): 73-88.

Brilha, J. \& Pereira, P. (2014): Património geológico de Portugal como base para ações de conservação da natureza e ordenamento do território. Comunicações Geológicas, 101(3):1211-1213.

Brilha, J. (2016): Inventory and quantitative assessment of geosites and geodiversity sites: a review. Geoheritage, 8(2): 119-134.

Carcavilla, L., Durán, J.J., Garcia-Cortés, A., López-Martinez, J. (2009): Geological heritage and geoconservation in Spain: past, present, and future. Geoheritage, 1(2-4): 75-91.

Choque, J.T.P. (2021): El rol de la afectividad em la Educación Ambiental. Revista de Psicologia, 1(25): 99-110.

Curovic, Z.; Curovic, M.; Spalevic, V.; Janic, M.; Sestras, P.; Popovic, S.G (2019): Identification and Evaluation of Landscape as a Precondition for Planning Revitalization and Development of Mediterranean Rural Settlements-Case Study: Mrkovi Village, Bay of Kotor, Montenegro. Sustainability 2019, 11, 2039. https://doi.org/10.3390/su11072039

De Wever, P., Alterio, I., Egoroff, G., Cornée, A., Bobrowsky, P., Collin, G., Page, K. (2015): Geoheritage, a national inventory in France. Geoheritage, 7(3): 205-24. 
Frankl, A., Lenaerts, T., Radusinovic, S., Spalevic, V., Nyssen, J. (2016): The regional geomorphology of Montenegro mapped using Land Surface Parameters. Zeitschrift fur Geomorphologie, 60 (1): 21-34. DOI: 10.1127/zfg/2016/0221.

Garcia, M.G.M., Alves, A., Campanha, G.A.C., Duleba, W., Faleiros, F.M., Fierz, M.S.M., Janasi, V.A., Martins, L., Raposo, M.I..B., Ross, J. L. S., Oliveira, M.E.C.B., Neves, B.B.B., Campos Neto, M.C., Machado, R., Passarelli, C.R. (2018): The inventory of geological heritage of the State of São Paulo, Brazil: methodological basis, results and perspectives. Geoheritage, 10(2): 239-258.

Gaspar Junior, L.A., Varajão, A.F.M.C., Santos, R.G., Moreno, M.M.T., Sarkis, M.F.R. (2010): Viabilidade de aplicação das coberturas argilosas da região de Alfenas na indústria cerâmica. Geociencias, 29(1): 71-80.

Hazbavi, Z. (2018): Importance of geology and geomorphology in watershed health assessment. Agriculture and Forestry, 64 (4): 277-287.

Henriques, M.H.P., Reis, R.P., Brilha J.B., Mota, T.S. (2011): Geoconservation as an Emerging Geoscience. Geoheritage, 3(2): 117-128.

IBGE - Instituto Brasileiro de Geografia e Estatística (2021): Censo Demográfico. Brasília: IBGE Cidades.

Pitombeira, R.S.S., Filho, F.C., Esmeraldo, G.G.S.L. (2018): Educação Ambiental e a Interdisciplinaridade em uma escola do campo. Revista Brasileira de Educação Ambiental, 13(1): 213-226.

Prochnow, D., Dechen, S.C.F., Maria, I.C., Castro, O.M., Vieira, S.R. (2005): Razão de perdas de terra e fator $\mathrm{C}$ da cultura do cafeeiro em cinco espaçamentos, em Pindorama (SP). Revista Brasileira de Ciência do Solo, 29(1): 91-98.

Renard, K.G., Foster, G. R., Weesier, G. A., Mccool, D. K., Yoder, D.C. (1997): Predicting soil erosion by water: a guide to conservation planning with the Revised Universal Soil Loss Equation (RUSLE). Washington: United States Department of Agriculture. 407 pp.

Renschler, C. S., and Harbor, J. (2002): Soil erosion assessment tools from point to regional scales-the role of geomorphologists in land management research and implementation. Geomorphology, 47 (2-4): 189-209.

Reverte F.C. \& Garcia M.G.M. (2016). The geological heritage of São Sebastião, SP: Inventory and potential use of geosites with scientific value. Revista Geociências, 35(4): 495-511.

Reverte, F.C., Garcia, M.G.M., Brilha, J., Moura. T.T. (2019): Inventário de geossítios como instrumento de gestão e preservação da memória geológica: exemplo de geossítios vulneráveis da Bacia de Taubaté (São Paulo, Brasil) Pesquisa em Geociências, 46(1): 1-23.

Ruiz, S., Britos, A., Diez, P., Vazquez, M. (2021): Mapeando com estudiantes secundários las problemáticas ambientales de la ciudad de Rio Gallegos. Concepción, 20(4): 441-453

Santana, D.B.; Bolleli, T.M.; Lense, G.H.E.; Silva, L.F.P.M.; Sestras, P.; Spalevic, V.; Mincato, R.L. (2021): Estimate of water erosion in coffee growing areas in Serra da Mantiqueira, Minas Gerais State, Brazil. Agriculture and Forestry, 67 (2): 75 88.

Scolforo, J. R.S., Mello, J.M., Silva, C.P.C. (2008): Inventário Florestal de Minas Gerais: Floresta Estacional Semidecidual e Ombrófila - Florística, Estrutura, Diversidade, Similaridade, Distribuição diamétrica e de altura, Volumetria e Tendências de crescimento e Áreas aptas para manejo florestal. (1nd ed.). Lavras: UFLA. 1029pp. 
Sestras, P., Salagean, T., Bilasco, S., Bondrea, M., Nas, S., Fountas, S., Spalevic, V., \& Cimpeanu, S. (2019). Prospect of a GIS based digitization and 3D model for a better management and land use in a specific micro-areal for crop trees. Environmental Engineering and Management Journal, 18(6): 1269-1277.

Silva, A.K.O. (2012): Ab'Sáber, Aziz Nacib. Os domínios de natureza no Brasil: Potencialidades paisagísticas. São Paulo: Ateliê Editorial, 2003. Revista de Geografia, 29(1): 252-258.

SISEMA (2019): Infraestrutura de Dados Espaciais do Sistema Estadual de Meio Ambiente e Recursos Hídricos. Belo Horizonte: Sistema Estadual de Meio Ambiente.

Sparovek, G., Van Lier, Q.J., Dourado Neto, D. (2007): Computer assisted Köppen climate classification: case study for Brazil. International Journal Climatology, 27(1):257-266.

Tavares, A.S.; Spalevic, V.; Avanzi, J.C.; Nogueira, D.A.; Silva, M.L.N.; Mincato, R.L. (2019): Modeling of water erosion by the erosion potential method in a pilot subbasin in southern Minas Gerais. Semin. Ciências Agrárias 2019, 40, 555-572.

Turbay, C.V.G., Valeriano, C.M. (2012): Litogeoquímica do Complexo Campos Gerais e granitoide intrusivos, Arqueano/Paleoproterozoico, Brasil. Revista Brasileira de Geociências, 42(4): 663-689.

UFV - Universidade Federal de Viçosa., CETEC-T - Fundação Centro Tecnológico de Minas Gerais., UFLA - Universidade Federal de Lavras., FEAM - Fundação Estadual do Meio Ambiente. (2010): Mapa de Solos do Estado de Minas Gerais: legenda expandida. Belo Horizonte: Fundação Estadual do Meio Ambiente. 53p.

Williams, M. (2019): Using spatial technologies in geoconservation and geotourism, Australian Institute of Geographers Conference (IAGC), 9-13 July, Hobart, Tasmania (2019) [Conference Extract]. 